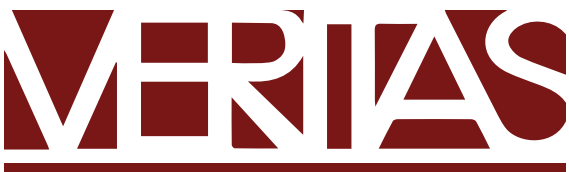

$\begin{array}{lllllllllll}\mathbf{P} & \mathbf{O} & \mathbf{R} & \mathbf{T} & \mathbf{O} & \mathrm{A} & \mathbf{L} & \mathbf{E} & \mathbf{G} & \mathbf{R} & \mathbf{E}\end{array}$

http://dx.doi.org/10.15448/1984-6746.2019.2.31482

\title{
CÍCERO, AQUINO E TEMAS JUSNATURALISTAS CONTEMPORÂNEOS'
}

\author{
Cicero, Aquinas and contemporary issues \\ in natural law theory
}

Cicero, Aquino y temas jusnaturalistas contemporáneos

\author{
Adam Seagrave ${ }^{2}$ \\ Universidade Estadual do Arizona, EUA. \\ Tradução de Bruno Rodrigo D'ambros ${ }^{3}$ \\ Universidade Federal do Paraná, Curitiba, PR, Brasil.
}

O advento da nova escola de direito natural, na última metade do século vinte, teve o efeito salutar de trazer Aquino para a discussão filosófica moral, jurídica e política contemporânea. Com a obra de Finnis, certo jusnaturalismo tomista foi considerado compatível tanto com a filosofia analítica e a jurisprudência quanto com os direitos naturais da

Original: SEAGRAVE, Adam. Cicero, Aquinas and contemporary issues in Natural Law Theory. In: The Review of Metaphysics, v. 62, n. 3, mar., 2009, p. 491-523. Copyright (c [2009] by The Review of Metaphysics. Publicado com permissão. Tradução de Bruno D’ambros.

2 Professor associado na Universidade do Estado do Arizona, EUA. E-mail: adam.seagrave@asu.edu

3 Mestre em Filosofia pela Universidade Federal de Pelotas (UFPel). Bacharel em Ciências Sociais pela Universidade Federal de Santa Catarina. Visitor Research Fellow na Universidade Hebraica de Jerusalém; doutorando em filosofia pela Universidade Federal do Paraná (UFPR), Curitiba, PR, Brasil. https://orcid.org/o000-0002-3101-3352. E-mail: dambrosbruno@gmail.com 
tradição liberal ${ }^{4}$. O impacto das tendências modernas de Finnis com o jusnaturalismo tomista, visto como um movimento maior dentro do catolicismo pós-Vaticano II, tem se tornado cada vez mais relevante em debates seculares dentro do liberalismo contemporâneo. Esse impacto pode ser claramente visto na recente tentativa de construir um "liberalismo jusnaturalista", que promete incluir as ideias centrais de cada tradição dentro de uma única e coerente filosofia política ${ }^{5}$.

No fervor de alguns círculos acadêmicos para tornar o jusnaturalismo tomista relevante em um contexto contemporâneo impregnado das doutrinas do liberalismo e guiado pelas exigências do rigor analítico, esse jusnaturalismo foi em grande parte desenraizado de sua base clássica. Esse desarraigamento é significativo principalmente porque o jusnaturalismo tomista se torna mais persuasivo quando é visto à luz de sua base clássica. Apesar disso, a interpretação do chamado Tratado da lei de Aquino (e as suas divergências) pelos novos teóricos jusnaturalistas pressupõe, em grande parte, a ausência de tal base ${ }^{6}$. Esse pressuposto não é infundado. Os dois candidatos a influenciadores de Aquino, Aristóteles e Cícero, foram amplamente considerados inadequados. O termo "lei natural" está totalmente ausente das obras de Aristóteles e a própria noção de "lei natural" parece ser amplamente estranha ao seu pensamento7. Embora as referências à "lei natural" abundem nas obras de Cícero, essa lei na-

\footnotetext{
4 FINNIS, John. Natural Law and Natural Rights. Oxford: Oxford University Press, 1980.

5 Cf. WOLFE, Christopher. Natural Law Liberalism, Cambridge: Cambridge University Press, 2006.

6 FINNIS, John; GRISEZ, Germain. The Basic Principles of Natural Law: A Reply to Ralph Mclnerny. American Journal of Jurisprudence, 26, 1981, p. 31.

7 Cf. STRAUSS, Leo. Natural Right and History, Chicago: University of Chicago Press, 1953, p.146-164. CROSSON, Frederick, Religion and Natural Law, American Journal of Jurisprudence, 33, 1988, p. 1-3. FORTIN, Ernest. Augustine, Thomas Aquinas and the Problem of Natural Law, Mediaevalia 4, 1978, p. 179-82. WOLFE, Natural Law Liberalism, p. 154-155. ZUCKERT, Michael. The Fullness of Being: Thomas Aquinas and the Modern Critique of Natural Law, The Review of Politics, 69, 2007, p. 42. Para as interpretações de Aristóteles que veem a lei natural como latente, embora não presente ainda nas obras de Aristóteles, ver SIGMUND, Paul. Natural Law in Political Thought, New York: University Press of America, 1971, p. 1-12 e MCARTHUR, Ronald. The Natural Law: A Perennial Problem, American Journal of Jurisprudence, 26, 1981, p. 16.
} 
tural parece ser pouco mais do que uma transmissão de ideias estoicas ${ }^{8}$ e, embora o jusnaturalismo de Aquino possa ter ressonâncias estoicas, a cosmologia que justifica a lei natural estoica foi claramente substituída na obra de Aquino por doutrinas cristãs. A partir dessas considerações, parece que o jusnaturalismo aquiniano é menos o ponto culminante de uma tradição precedente do que o protótipo de uma doutrina do direito natural inteiramente nova, centrada na famosa teoria das "inclinações"

Além disso, a carência na identificação de influências pré-cristãs no jusnaturalismo de Aquino deu suporte a argumentos contra o direito natural. A questão colocada por Leo Strauss em Direito natural e história capta com precisão o ponto de partida para tais argumentos: "é mister perguntar se a lei natural, como Tomás de Aquino entende, é uma lei natural estritamente falando, isto é, uma lei cognoscível para a mente humana não auxiliada por Deus, uma mente não iluminada pela revelação"10. É difícil evitar responder negativamente à questão de se a lei natural tomista é coextensiva com a crença cristã. O próprio Finnis é levado a essa conclusão ao apresentar uma teoria da lei natural independente da "questão da existência ou da natureza de Deus;"11 sem essa referência a Deus, a lei natural é "apenas analogicamente uma lei"12.

Deste veredicto, parece que o debate entre defensores e oponentes do jusnaturalismo se caracteriza por uma concordância fundamental. A questão de "se a lei natural existe" está fechada. Agora se pergunta "se existe algo como uma lei natural" ou "se há um padrão natural e objetivo

\footnotetext{
8 Para uma expressão mais clara dessa interpretação, veja WEINREB, Lloyd L. Natural Law and Justice, Cambridge, Mass: Harvard University Press, 1987, p. 39-40; também ver STRAUSS, Leo, Natural Right, p. 154; SIGMUND, Natural Law, 20-25; HOLTON, Marcus Tullius Cícero, em History of Political Philosophy, 3. ed., ed. Leo Strauss e Joseph Cropsey, Chicago: University of Chicago Press, 1987, p. 155-175; HORSLEY, Richard A. The Law of Nature in Philo and Cícero, The Harvard Theological Review 71, April 1978, p. 35-59; WOLFE, Natural Law Liberalism, p. 156-157.

9 Tomás de Aquino, Summa Theologica, Trad. Padres da província dominicana inglesa, New York: Benziger Bros., 1948, I- II, q. 94, a. 2; doravante ST.

10 STRAUSS, Natural Right, p. 163.

"FINNIS, Natural Law, p. 49.

12 Ibid., p. 280
} 
para a ação humana"13 ou mesmo "se certas ideias associadas com a lei natural podem ser benéficas ou úteis em um contexto de esquerda-progressista"14. Estritamente falando, a questão de uma lei natural foi tudo, menos abandonada. A "lei natural" se tornou um mero dialeto aristotélico-cristão, ${ }^{15}$ mantido por deferência a sua linhagem histórica, mas enfraquecido no sentido por força da moderna investigação analítica.

A intenção deste artigo é reabrir a pergunta sobre a existência de uma lei natural, no sentido estrito, e renovar a sua compreensão, estabelecendo bases substanciais para o jusnaturalismo tomista na filosofia pré-cristã. $O$ estabelecimento de tais bases suporta essa argumentação de importância central para a compreensão da lei natural de São Tomás, de que um jusnaturalismo tomista não precisa se basear em suposições ou crenças especificamente cristãs. $\mathrm{O}$ crucial nesse argumento reside em uma apreciação do papel ativo e distinto de Cícero na formação da tradição jusnaturalista. Contrário às interpretações amplamente aceitas das obras de Cícero, a lei natural de Cícero não é uma mera transmissão ou elaboração de ideias estoicas. Embora Cícero claramente se baseie nestas ideias, uma atenção mais cuidadosa à teoria da lei natural que ele apresenta, revela uma afinidade maior à filosofia moral de Aristóteles. Anterior ao advento do cristianismo e bem antes do surgimento de Aquino, Cícero derivou um jusnaturalismo coerente e convincente, embora rudimentar, da compreensão aristotélica da natureza humana. A lei natural de Aquino é mais adequadamente entendida e mais convincente quando é vista como uma continuação e culminação desta lei natural aristotélico-ciceroniana do que como a incipiente expressão de uma "nova" lei natural.

\footnotetext{
13 Estas duas primeiras questões eu considero como as preocupações básicas da nova teoria da lei natural.

14 Esta questão é tratada por Wolfe em Natural Law Liberalism.

15 Ver a descrição de Fortin da lei natural como um "tipo de termo incorreto, introduzido na tradição de algum modo acidental", FORTIN, Ernest. The New Rights Theory and the Natural Law, Review of Politics, 44, Oct. 1982, p. 610.
} 
Embora Cícero sempre tenha sido estimado por sua retórica, só tardiamente recuperou-se o prestígio acadêmico que sua filosofia política teve no medievo. ${ }^{16}$ Apesar desta renovação de Cícero como filósofo político, sua abordagem sobre a lei natural ainda é considerada de segunda mão e o grau em que ele apresenta seu jusnaturalismo é frequentemente questionado.

Esta consideração como "segunda mão" tem a ver com o senso comum de que "Cícero estava repetindo ideias estoicas"17 sobre a lei natural. Caracterizar o jusnaturalismo ciceroniano deste modo o põe em uma série de dificuldades. A primeira dificuldade envolve a cosmologia estoica que serve de base para a lei natural, uma cosmologia que havia sido desacreditada pelo próprio Cícero em sua De Natura Deorum e foi amplamente descartada desde a época de Cícero. Se o jusnaturalismo de Cícero é pouco mais do que uma transmissão da lei natural estoica, com a cosmologia duvidosa que a acompanha, então a lei natural de Cícero não poderia ter sido levada a sério por um cristão como Aquino e não poderia ser persuasiva hoje. Mesmo quando a caracterização estoica da lei natural de Cícero não é aceita em sua forma exata, porém, ela é considerada no máximo como um estoicismo moderado ou "transformado"18 ao invés de uma doutrina crível em si mesma com influências estoicas.

A plausibilidade desta caracterização decorre da aparente relutância de Cícero em falar em sua própria voz em seus escritos. No De re publica, Cícero mesmo fala somente por prefácios, deixando o diálogo primariamente para Cipião, Lélio e Filo. No De legibus, apesar do próprio Cícero aparecer como o interlocutor primário, ele explicitamente indica que está seguindo o padrão posto por Platão no plano geral de sua obra ao dedicar diálogos separados

\footnotetext{
16 Ver NICGORSKY, Walter. Cícero and the Rebirth of Political Philosophy, The Political Science Reviewer 8, 1978, p. 63-102.

17 HORSLEY, The Law of Nature, p. 36.

18 Ibidem, p. 58.
} 
mas interrelacionados à "República" e a sua "Leis." ${ }^{19}$ No primeiro livro, além do mais, Cícero sustenta que ele está "seguindo o método dos filósofos; não aqueles dos primeiros tempos, mas aqueles que construíram escolas, por assim dizer, para a disseminação de sabedoria, ${ }^{20}$ a saber, os estóicos. ${ }^{21}$ Que Cícero estava cônscio de sua tendência em aparecer para "humildemente aceitar a autoridade dos outros" ${ }^{\prime 22}$ em seus escritos é evidenciado pela censura que ele coloca na boca de Ático nesta conjuntura do diálogo. Ático antecipa o modo que Cícero será interpretado por acadêmicos séculos mais tarde, ao acusar Cícero de ser "o tipo de homem que não segue seu juízo próprio em um debate." ${ }^{23} \mathrm{~A}$ resposta concisa de Cícero serve como um aviso severo para seus leitores: non semper, Tite.

No De finibus, Cícero relata uma série de diálogos onde ele se apresenta como participante, embora todo o trabalho seja dirigido a Bruto para sua aprovação. Em cada diálogo, além do mais, Cícero está preocupado não simplesmente em apresentar sua própria visão, mas sim em criticamente avaliar aquelas dos epicuristas, estóicos e peripatéticos. Ao refutar os epicuristas, Cícero toma uma posição amplamente estoica; ao responder aos estóicos ele adota uma perspectiva peripatética e em sua breve crítica aos peripatéticos, Cícero novamente toma o ponto de vista estóico.

O De officiis, apesar de não ser um diálogo, é semelhantemente dirigido para um destinatário específico, neste caso o próprio filho de Cícero. Nessa obra, Cícero novamente explicita sua intenção de seguir

19 CICERO, De Legibus, trad.. C. W. Keyes, Cambridge, Harvard University Press, 1970, livro 1, §15, p. 313.

20 Ibidem, 1.36, p. 337.

${ }_{21}$ Ibidem, 1.36, p. 337. As passagens que imediatamente se seguem a esta afirmação indicam que Cícero se refere especialmente aos estóicos, embora nestas passagens Cícero também afirme que a Antiga Academia, os Peripatéticos e os Estóicos concordam substancialmente. Zeno simplesmente "mudou a terminologia sem alterar as ideias" das duas primeiras escolas (1.38, p. 339). Parece, então, que Cícero não está seguindo qualquer escola particular na essência de sua exposição (visto que elas todas concordam sobre este ponto), mas está seguindo a maneira estoica de expressar.

22 Ibidem, 1.36, p. 337.

23 Ibidem. 
uma escola particular, os estóicos (e particularmente Panécio). O modo no qual Cícero qualifica esta admissão é, porém, digno de nota: "devo, portanto, seguir principalmente os estóicos, não como tradutor, mas, como é costume, tomarei por minha própria escolha e discrição de tais fontes na medida e de acordo com o meu propósito"24.

Esta afirmação é relevante não somente para uma interpretação adequada do De officiis, mas também para uma interpretação de cada uma das outras obras alegadamente de segunda mão de Cícero. Ao indicar que seu "costume" geral envolve um tipo particular de "seguimento", a saber, um que envolva o exercício da "discrição" e discriminação em um modo que se encaixe em seu "propósito," Cícero reitera e clarifica sua resposta a Ático no De legibus. Non semper não significaria que Cícero usualmente segue os outros irrefletidamente e ocasionalmente para suportar seu próprio entendimento; mas sim que Cícero somente repete as opiniões dos outros quando elas são relevantes para o "propósito" de sua própria exposição.

Considerando esta passagem e outras com significado semelhante, muitos comentaristas rejeitaram a posição simplista de que as afirmações de Cícero sobre a lei natural são uma reprodução irrefletida dos princípios estóicos ${ }^{25}$. A próxima questão, de saber se o propósito adequado de Cícero é apresentar um ensino da lei natural (no sentido estrito), é frequentemente respondida negativamente. Essa resposta aparece em duas formas principais:

A primeira forma descreve Cícero como refletindo ideias médio-platônicas, adotadas primeiro por Antíoco de Ascalon, sobre um "deus

\footnotetext{
24 CICERO, De Officiis, trad. Walter Miller, Cambridge, Mass.: Harvard University Press, 2001, livro 1, §6, p. 9 (grifo nosso).

25 Ver as interpretações de STRAUSS, Natural right, p. 154; HORSLEY, The Law of Nature; NICGORSKY, Cícero's Paradoxes and His Idea of Utility, Political Theory 12, Nov., 1984, p. 557-578; HOLTON, Marcus Tullius Cícero; CROSSON, Religion and Natural Law; e ARKES, Hadley. That "Nature Herself Has Placed in Our Ears a Power of Judging:" Some Reflections on the "Naturalism" of Cícero, In: Natural Law Theory: Contemporary Essays, ed. Robert P. George, Oxford: Oxford University Press, 1992, p. 245-277.
} 
transcendente que era o legislador bem como o pai e criador do mundo." ${ }^{26}$ Se um "deus transcendente" é a fonte imediata da lei natural, porém, esta lei não se qualifica como estritamente "natural" ${ }^{27}$ tal como uma lei seria propriamente chamada de "divina" e somente secundariamente ou metaforicamente de "natural". De acordo com esta interpretação da lei natural de Cícero como uma lei "divina", Cícero antecipa a mais explícita absorção da lei natural na teologia que alegadamente ocorre no medievo cristão. ${ }^{28}$ Se a lei natural de Cícero é realmente uma lei divina por natureza, não é natural no sentido próprio do inerente na natureza. ${ }^{29}$ Portanto, o propósito próprio de Cícero não é apresentar uma teoria da lei natural, mas sim substituir a lei natural estoica imanente por um lei transcendente, divina e eterna.

A segunda forma de resposta segue, em alguma medida, a conclusão da primeira. Na visão de Leo Strauss e outros ligados a ele, o propósito último de Cícero é apresentar a lei natural estoica de um modo que revele a incoerência da própria lei natural e sua incompatibilidade com a mais crível doutrina do direito natural. ${ }^{30}$ Isso envolve uma interpretação de Cícero à luz de uma crítica particular do jusnaturalismo, a saber que ela representa a intersecção incoerente de um direito natural e alguma forma de lei eterna ou divina. Cícero, ao perceber que a noção de lei natural não pode ser significativamente distinguida daquela de lei divina e que os assuntos

\footnotetext{
26 HORSLEY, The Law of Nature, p. 59.

27 Ver STRAUSS, Natural Right; FORTIN, The New Rights Theory; e CROSSON, Religion and Natural Law. Um deus transcendente pode ser ontologicamente a última ou a primeira fonte da lei natural, mas a real noção de uma lei natural em um sentido estrito mantém a distinção entre esta lei ou a lei divina ou uma lei eterna que é diretamente promulgada ou imediatamente reside em Deus. Aquino mantém esta distinção nas questões sobre a lei na Summa. HORSLEY, The law of nature, p. 58.

28 HORSLEY, The Law of Nature, p. 58.

29 Esta distinção é emprestada da análise de Crosson em Religion and Natural Law.

30 Ver STRAUSS, Natural Right, p. 154; HOLTON, Marcus Tullius Cícero; ver também ARKES, Some Reflections, p. 274.
} 
humanos não admitem regras "categóricas" mas devem ser guiados pelo padrão da lei natural, ${ }^{31}$ rejeita as afirmações superficiais sobre a lei natural.

Eu proponho o retorno à questão de se Cícero apresenta realmente um ensinamento próprio, genuíno e coerente da lei natural, argumentando que, em várias afirmações de Cícero sobre o tema, surge uma continuidade subjacente, enraizada numa compreensão aristotélica da natureza. Essa compreensão é desenvolvida de tal modo que a lei é vista como necessariamente inerente à natureza humana e implícita por sua própria descrição.

A passagem mais frequentemente citada nos escritos de Cícero sobre a lei natural é a aquela de Lélio no terceiro livro do De re publica. Ao responder ao ataque falso de Filo sobre a base natural da lei, Lélio afirma que

[...] a verdadeira lei é razão correta de acordo com a natureza, tem aplicação universal, é imutável e eterna e chama ao dever por suas prescrições e evita o mal por suas proibições. E ela não assenta suas prescrições ou proibições sobre os bons homens em vão, embora não tenham qualquer efeitos sobre os ímpios. É um pecado tentar alterar sua lei, nem é permissível tentar repelir qualquer parte dela, é impossível aboli-la inteiramente. Nós não podemos ser liberados de suas obrigações pelo senado ou pelo povo, e nós não precisamos olhar fora de nós mesmos para um expositor ou intérprete dela. ${ }^{32}$

Apesar de este trecho enfatizar o caráter "natural" da "verdadeira lei", a última metade de sua exposição introduz elementos de ambiguidade:

\footnotetext{
${ }^{31}$ A segunda forma de crítica da noção de uma lei natural como excessivamente rígida ou categórica não será dirigida diretamente no que se segue, embora uma resposta para ela é insinuada pela afirmação simultânea de Aquino da imutabilidade (em um sentido) e a flexibilidade (em outro sentido) da lei natural. Ambas as características da lei natural também aparecem nos escritos de Cícero e nas afirmações paradoxais de Aristóteles sobre a justiça natural na Ética nicomaquéia 5.7.1134b20 - 1135a5.

32 CICERO, De Re Publica, trad. C. W. Keyes, Cambridge, Mass.: Harvard University Press, 1970, livro 3 §33, p. 211.
} 
[...] e não haverá diferentes leis em Roma e Atenas, ou diferentes leis agora e no futuro, mas uma eterna e imutável lei será válida para todas as nações e todos os tempos, e haverá um só mestre e legislador, Deus, sobre todos nós, pois ele é o autor desta lei, seu promulgador e seu juiz de execução. Quem desobedecer está fugindo de si mesmo e negando sua natureza humana, e por razão deste fato ele sofrerá a pior das penas, mesmo se ele escapar do que é comumente considerado pena.

A menção a "deus" como o "autor, promulgador e juiz" da verdadeira lei parece estabelecer esta lei como uma lei divina. Isto parece, porém, contradizer tanto a controvérsia de que "nós não precisamos olhar fora de nós mesmos" para descobrir a verdadeira lei, e a afirmação de que contestar essa lei não é só desobedecer Deus, mas "negar a natureza humana" que inclui o seu mecanismo próprio, adequado e eficaz de execução.

Embora muito mais seja feito do fato de que esta afirmação é dada por Lélio e não por Cipião ou pelo próprio Cícero em seu próprio nome, esse fato não indica por si mesmo a dissociação de Cícero das ideias expressas nele. A evidência textual relevante de fato sugere precisamente o contrário.

Em uma rara quebra do diálogo, Cícero, o narrador da De re publica, descreve a recepção das observações de Lélio ante os seus interlocutores: "segundo estas palavras de Lélio, todos expressaram seu grande prazer em suas observações; exceto Cipião, cujo deleite, além do resto, foi quase levado pelo entusiasmo"33. Essa passagem mitiga, em larga medida, as dificuldades interpretativas associadas com o relato de opiniões de personagens particulares no diálogo do próprio Cícero. Se "todos" (aparentemente incluso Filo, cético acadêmico e primeiro oponente da lei natural) estão deleitados no discurso de Lélio, há pouca oportunidade de alinhar Cícero com outro interlocutor em oposição a Lélio. Isso é particularmente aparente no fato

33 Ibidem, 3.42, p. 217. 
de que Cipião, que é mais comumente tomado como intérprete de Cícero no diálogo, é "levado pelo entusiasmo" nas observações de Lélio. Embora Cícero tenha se desprendido da aprovação geral das palavras de Lélio ao colocar essa passagem na voz de um de seus personagens, ele indica que leva as declarações de Lélio a sério interrompendo momentaneamente o fluxo do diálogo para interpor a sua própria voz.

Além do mais, ao argumentar com a sua própria voz, contra os epicuristas em De finibus, Cícero cita o discurso de Lélio em De re publica, com aprovação ${ }^{34}$. Também falando em sua própria voz no primeiro livro, em De legibus, Cícero está, primeiramente, preocupado em oferecer argumentos adicionais em suporte da primeira controvérsia de Lélio de que a justiça e a lei são fundadas na natureza ${ }^{35}$. Embora essa evidência não demonstre a identificação não qualificada de Cícero com as declarações de Lélio quanto à lei natural ${ }^{36}$, indica que essas afirmações, longe de serem sutilmente rejeitadas por Cícero, são, em grande parte, consoantes as suas próprias opiniões. A próxima tarefa, então, é mostrar como a definição estendida de Lélio pode ser descompactada de um modo ciceroniano.

A primeira questão diz respeito ao nível de correspondência entre a descrição de Lélio de "verdadeira lei", ou vera lex, e as formulações que aparecem nos escritos de Cícero como "lei da natureza"37 "lei universal", ${ }^{38}$ "lei suprema" 39 e "lei dos povos"40. No primeiro livro do De legibus, cada uma dessas formulações alternativas aparece, e é tecida junta por Cícero,

\footnotetext{
34 CíCERO, De Finibus Bonorum et Malorum. Trad.: H. Rackham. Loeb Classical Library, Cambridge, Mass: Harvard University Press, 2006, livro 2, §59, p. 149.

35 Ver especialmente 1.35, p. 335-337.

36 Ver De Legibus, 1.19, p. 317-319, onde Cícero afirma que "a lei é a mente e razão do homem prudente, o padrão pelo qual a justiça e a injustiça são medidas." Nessas passagens Cícero adiciona um elemento de flexibilidade à rigidez das afirmações de Lélio (sem necessariamente suplantar esse elemento de rigidez).

37 De Officiis, 3.69, p. 339. De Legibus, 1.56, p. 361.

38 Delegibus 1.14, p. $313 ; 1.17$, p. 315.

39 Ibidem, 1.19, p. 319.

40 De Officiis 3.69, p. 339-41.
} 
no início de sua discussão. Nesse contexto, Cícero expressa a opinião dos "homens mais instruídos" que definem a lei como a mais alta razão, implantada na natureza, que prescreve o que deve ser feito e proíbe o oposto. Essa razão, quando firmemente fixada e completamente desenvolvida na mente humana, é lei. ${ }^{41}$ Essa opinião, que parece correta a Cícero ${ }^{42}$, conecta a lei com a mesma "razão" e a natureza humana que forma os princípios da "verdadeira lei" na noção de Lélio de "reta razão"43, e introduz uma ambiguidade similar ao se referir ao "deus de poder transcendente" que regra sobre a comunidade de deuses e homens ${ }^{44}$.

Ao desenvolver a descrição de Lélio da "lei verdadeira", Cícero indica que as várias formulações acima mencionadas se referem à mesma lei considerada em relação a diversas relações. Essa lei é descrita como "verdadeira" e "suprema" para distingui-la da "definição de lei do povo", isto é, decretos escritos que são estabelecidos pelos seres humanos e lidam amplamente com detalhes; ${ }^{45}$ é descrita como a "lei universal" e a "lei dos povos", uma vez que não é "restrita" a qualquer estado ou nação particular, como é a lei civil ${ }^{46}$; é descrita de maneira mais adequada como a "lei da natureza" ou a "lei natural," já que o seu próprio princípio de derivação reside na natureza humana ${ }^{47}$.

Ao desenfatizar essa última relação da lei da natureza humana e apreender o elemento do divino na explicação de Cícero, muitas vezes se argumenta que Cícero se dissocia de suas afirmações no primeiro livro do De Legibus, da mesma forma que se pensa ocorrer em De re publica. Esse argumento diz que Cícero apresenta a lei natural nesse contexto como

\footnotetext{
${ }^{41}$ De Legibus 1.18, p. 317

42 Ibidem, 1.19, p. 317. Ibidem, 1.

43 Ibidem, 1.23, p. 321-323.

44 Ibidem.

45 Ibidem, 1.19, p. 319.

46 Ibidem, 1.17, p. 315.

47 Ibidem, 1.17-18, p. 315-317.
} 
uma espécie de "mentira nobre" que, embora útil "para fins políticos," indefensável do ponto de vista filosófico ${ }^{49}$. Nesse caso, como no primeiro, a evidência do texto parece contrariar esta afirmação. O próprio Holton (1987) cita tal passagem na qual Cícero afirma que os seus argumentos para a lei natural parecem-no "geralmente e majoritariamente" $\operatorname{corretos}^{50}$. Além disso, antes de embarcar em sua discussão da lei natural, Cícero distingue o seu propósito no De legibus daquele do advogado comum ao afirmar que

embora eu não considere que os que se dedicam a esta profissão careçam de uma concepção de lei universal, ainda que tenham estudado a lei civil apenas o suficiente para finalidade de utilidade pública. Contudo isso é pouco quanto ao aprendizado, embora, no que tange a finalidades práticas, seja indispensável51.

Essa passagem indica que a "finalidade" de Cícero no De legibus vai além do "utilitarismo" e "pragmatismo." Ele deseja, ao invés, que isso equivalha a algo "na medida em que a aprendizagem está em causa", ou seja, filosoficamente.

É importante também notar o papel da referência ao divino na explicação de Cícero no De legibus, bem como a de Lélio em De re publica. Em ambos os lugares, esse elemento é anexado com um argumento da própria natureza humana. A preocupação abrangente de Cícero é com "os dons da natureza ao homem"52 e como a indicação da fonte desses dons dá a discussão certa riqueza, esses dons são o campo adequado "dos mistérios mais profundos da filosofia" 53 e não da teologia. A "natu-

\footnotetext{
48 CROSSON, Religion and Natural Law, 6. Ver também HOLTON, Cícero, p. 170-177.

49 Para Cícero, na verdade, o fato de que uma certa doutrina é politicamente conveniente é na verdade uma evidência para sua verdade teórica. Ver a tentativa de Cícero de reconciliação do expediente e o moralmente correto em no livro 3 do De Officiis.

50 HOLTON, Cícero, p. 171.

${ }^{51}$ De Legibus 1.14, p. 313.

${ }^{52}$ De Legibus, 1.16, p. 315.

53 Ibidem.
} 
reza da justiça" e a sua origem na lei "deve ser procurada na natureza do homem". ${ }^{54} \mathrm{O}$ elemento divino está presente não como uma premissa necessária, mas como uma "teoria provável que pode ser avançada para complementar um exame da natureza do homem"55.

Embora Cícero pareça exigir a curiosa admissão de Ático da governança divina da natureza para a sua posterior discussão sobre a lei natural, tanto a maneira como Cícero faz o seu apelo e aquela em que é admitida por seu amigo epicurista apoia o papel essencial da ideia de um deus transcendente ao chegar a uma compreensão básica da própria natureza ${ }^{56}$. $\mathrm{O}$ apelo de Cícero começa com a existência postulada do "poder dos deuses imortais", mas é posteriormente diluído para formulações mais modestas em termos de "natureza, razão, poder, mente e vontade"57. O consentimento de Ático a este recurso, ademais, não ocorre de modo inexplicável. O motivo exato que Ático dá ao aceitar a afirmação de Cícero repousa no "canto dos pássaros sobre nós e no balbuciar dos riachos" ${ }^{\prime 8}$, isto é, em uma observação dos fenômenos naturais. Portanto, à luz do fato de que a discussão de Cícero sobre lei natural não inclui a existência de deus como uma premissa lógica necessária, ${ }^{59}$ Ático pode ter dado a Cícero o conceito de "natureza" que, na verdade, é tudo o que Cícero realmente exigiu em primeiro lugar.

É o conceito de natureza em particular, e a razão como sua característica distintiva, que nós agora devemos atentar para mostrar como ela se torna associada com a "lei" nos escritos de Cícero. A fundação do conceito, para Cícero, repousa no lugar específico dos seres humanos dentro de uma hierarquia de naturezas. No início do De officiis, Cícero

\footnotetext{
54 Ibidem, 1.17, p. 317.

55 Ibidem, 1.24, p. 323.

${ }^{5}$ Esse papel não essencial para o deus transcendente deve ser entendido em sentido mais epistemológico do que ontológico.

57 Ibidem, 1.21, p. 319-321.

58 Ibidem.

59 Em suporte a este ponto ver também a referência de Cícero à função da "natureza, sozinha e isolada" em 1.27, p. 327.
} 
descreve as características e "instintos" de cada espécie de criatura viva"60. Esses instintos, primariamente, incluem a autopreservação e a reprodução, junto a outros instintos que são instrumentais a esses dois. Embora o homem possua estes impulsos animais, ele também exibe a "diferença marcada" da razão ${ }^{61}$.

Esta descrição ecoa a afirmação de Cícero no De legibus de que a "razão, que sozinha nos eleva sobre o nível das bestas, é certamente comum a todos nós"6z. Em ambas as explicações, Cícero começa listando as capacidades e inclinações adequadas e inerentes à razão. A capacidade própria da razão inclui a habilidade de "esboçar e diferençar," "63 "discutir e resolver problemas"64, "perceber as causas das coisas," ${ }^{165} \mathrm{e}$ "conectar e associar o presente ao futuro"66. As inclinações próprias da razão incluem o impulso para formar comunidades com outros seres humanos, "prover um estoque de coisas" ${ }^{\prime 67}$ tanto para si mesmo como para os outros em seu cuidado, e "procurar pela verdade"68.

Cícero também segue sua discussão sobre a razão em ambas as explicações com uma descrição similar das "tendências más"69 inerentes à natureza humana. Estas tendências contrárias ao bem da razão são geralmente subsumidas sobre o título de "prazer sensual"70. Prazer sensual, ademais, é associado com "gado e outras bestas" que são "impelidos" por sua busca de prazer de um modo irracional e irrefletido ${ }^{71}$.

\footnotetext{
60 De Officiis, p. 13.

61 Ibidem.

62 De Legibus, 1.30, p. 329.

63 Ibidem.

64 Ibidem.

65 De Officiis, 1.11, p. 13.

66 Ibidem.

${ }_{67}$ Ibidem, 1.12, p. 15.

68 Ibidem.

69 De Legibus, 1.31, p. 331.

70 Ibidem.

${ }^{71}$ De Officiis 1.105. d.107.
} 
O ponto crucial aqui é que ambas as inclinações, aquelas pertencentes à razão e aquelas pertencentes ao apetite sensual, são naturais aos seres humanos ${ }^{72}$. O problema de decidir entre essas inclinações, na determinação correta das ações não existe para Cícero pelo simples motivo de que o aspecto racional do homem é claramente superior ao seu animal. Assim, Cícero explica a virtude da "propriedade" e seu "dever" correspondente, que envolve o dever geral de viver de acordo com a natureza, afirmando que a atividade essencial do espírito e também da natureza é dupla: uma força é o apetite, que impulsiona um homem de tal modo; a outra é razão, que ensina e explica o que deve ser feito e o que deve evitado. O resultado é que a razão prescreve e o apetite obedece ${ }^{73}$.

Embora essa passagem apareça no contexto da discussão sobre as virtudes de Cícero, é uma reminiscência impressionante das muitas formulações da lei natural pelos escritos de Cícero. Imediatamente lembra-se da definição de Lélio: "a verdadeira lei é a reta razão em concordância com a natureza... ela chama ao dever por suas prescrições, e evita o mal por suas proibições" Para os seres humanos, viver de acordo com a natureza simultaneamente implica a presença da virtude e obediência à lei natural.

Cícero assim deriva tanto a lei natural e as virtudes da única "fonte" da natureza humana ${ }^{74}$. Esta derivação inicialmente parece ser um exemplo primário da "falácia naturalista" que, de acordo com alguns, decisivamente refuta "a imagem mais popular da lei natural" e impulsiona o projeto dos novos jusnaturalistas 75 . Cícero, com efeito, constrói uma teoria "normativa" das virtudes e da lei natural usando somente uma explicação "descritiva" da natureza humana. Será lembrado, porém, que a explicação descritiva

\footnotetext{
72 Neste ponto da explicação de Cícero das inclinações humanas, ver NICGORSKY, Cicero's Paradoxes, p. 564-566.

73 De Officiis, 1.101, p. 103. Eu alterei a tradução da primeira frase para incluir "natureza" que está ausente no latim.

${ }_{74}$ De Legibus 1.18. d. 317.

75 FINNIS, Natural Law, p. 33; GEORGE, Robert. Natural Law and Human Nature, in Natural Law Theory: Contemporary Essays, p. 32.
} 
de Cícero envolvia dois tipos de "fatos" em uma complexa relação de ordem hierárquica e oposição potencial. O primeiro aspecto desta relação concerne sobre a superioridade da razão e suas determinações aos impulsos cegos do apetite sensual. O segundo expressa o poder do apetite sensual para reverter essa hierarquia e influenciar a ação humana, apesar das determinações da razão. Da capacidade de reflexão e deliberação da razão, assim como seu impulso de direcionar e reprimir as paixões potencialmente rebeldes, surge a possibilidade humana de escolha.

A noção adequada de lei surge desta explicação descritiva de dois modos relacionados. No primeiro, a natureza humana implica uma lei inerente do fato de que suas inclinações próprias são somente levadas da potencialidade para a atualidade de acordo com o poder contingente de escolha ${ }^{76}$. Em outras palavras, o "é" da natureza humana está em um estado perpétuo de conflito potencial com o "é" das ações humanas particulares. Os fatos da natureza humana incluem a inclinação primária ou regra geral para agir de acordo com esta natureza; esta regra geral se torna um comando quando ela se confronta com a indeterminação de escolha.

A regra de agir de acordo com a natureza humana possui a forma de um comando, ao invés de um conselho ou recomendação, visto que ela inclui a ameaça de punição e a promessa de recompensa (os próprios efeitos da noção de um comando) ${ }^{77}$. A punição ameaçada pelo comando ou lei da natureza consiste primariamente na alienação de si mesmo da natureza, ou a falha em ser em ato o que se é fundamentalmente e potencialmente, que para Cícero é a mais severa das penas. Essa penalidade, embora pareça leve como resultado do seu afastamento de experiências tangíveis de danos físicos ou materiais, é necessariamente mais dolorosa

\footnotetext{
76 Ver a derivação de Cícero de "lei" da ideia de "escolha" como um dos elementos de sua noção própria no De Legibus 1.19, p. 317.

77 Deste modo, como Cícero faz, pode-se estabelecer a existência de uma lei ou um comando da existência de seus efeitos próprios (efeitos que poderiam se seguir somente de uma lei ou comando). Este é um tipo de argumento efeito-causa (quid) que Fortin, por exemplo, não permite em sua discussão da legalidade da lei natural em The New Rights Theory.
} 
do que estas, uma vez que o desejo mais fundamental de qualquer ser natural consiste na preservação de sua natureza. Deste modo o comando da natureza humana também inclui a recompensa da virtude, isto é, a realização e a conclusão eminentemente desejáveis da natureza. Além disso, esse conflito potencial e este comando implícito estão ambos os presentes no ser humano individual, que sabe que o cumprimento de sua natureza exige atuar a pedido da razão. Assim, a lei natural deriva sua existência como lei dos fatos interrelacionados da natureza humana. Existe como um comando geral que pode ser ou seguido ou rejeitado, e inclui recompensas e penas relacionadas à conformidade ou ao desvio ${ }^{78}$; e é universalmente promulgada para sujeitos cognoscentes.

De segundo modo, a lei natural existe por meio de sua instanciação nos comandos particulares para a ação que são emitidos pela razão do indivíduo em resposta a circunstâncias particulares. É desse segundo modo que a "lei é a mente, a razão do homem prudente, o padrão pelo qual a justiça e a injustiça são medidos"79. Considerando que o sujeito da lei natural no primeiro modo é todo o ser humano, no segundo modo o sujeito é o apetite sensual. Uma vez que a natureza da razão, incluindo suas inclinações próprias, implica direcionar as ações do ser humano todo, deve emitir comandos particulares para o mais baixo apetite e conseguir seu apoio. Esse apetite, porém, não se opõe aos comandos da razão e é capaz de determinar as ações humanas apesar deles. Esse poder de oposição e resistência, como em sua manifestação primeira e mais geral, elimina a possibilidade de um tipo de determinação despótica e necessita

\footnotetext{
${ }^{78}$ A distinção entre penas e recompensas "intrínsecas" e "externamente impostas" é crucial para um entendimento da lei natural. Embora penas e recompensas sejam na verdade os efeitos próprios do comando e da lei, estas não precisam ser impostas por algum "observador" externo, como Crosson, Fortin e muitos outros advogam. Se uma lei comanda algum bem, a desobediência desta lei necessariamente implica a privação do bem. Esta pena é uma consequência interna do ato de desobediência em si mesmo, e não algo anexado à desobediência após o fato. 79 De Legibus, 1.19, p.317-319. Eu substitui “inteligente" na tradução por "prudente” para um latim mais acurado.
} 
de uma regra pela lei. ${ }^{80}$ Portanto, nesse segundo modo, o indivíduo, ao seguir as injunções da manifestação mais geral da lei natural, emite comandos para o seu apetite que possuem o caráter da lei natural na forma de participação particular ou instanciação.

Ausente, esta explícita derivação da lei natural, a explicação de Cícero da natureza humana é, ademais, notavelmente consonante com aquela fornecida por Aristóteles. Na Física, Aristóteles define "natureza" em geral tanto em contraposição à sorte e ao acaso como em o que é "sempre ou majoritariamente" ${ }^{81}$ e como inerente aos seres como a fonte ou causa de seu movimento e repouso. ${ }^{82} \mathrm{O}$ último aspecto, que constitui a definição essencial de "natureza", é identificado com a matéria de uma coisa no sentido de potência ou substrato necessário para o movimento ou mudança e é identificado com a forma (isto é, a alma) no sentido de atualidade ou preenchimento deste movimento ${ }^{83}$. Ao aplicar esta discussão da natureza em geral para o seres humanos na Ética, Aristóteles começa, como faz Cícero, alocando a natureza humana dentro de uma hierarquia de outras naturezas. ${ }^{84}$ Ao dar a natureza humana o mesmo elemento próprio (formal) identificado por Cícero, a razão, Aristóteles continua a derivar as noções de felicidade humana e virtude. No curso desta derivação, Aristóteles encontra os mesmos elementos conflitantes de natureza humana que são notados por Cícero. Aristóteles divide a alma humana (que é natureza humana no sentido de forma) em elementos racionais e irracionais, com o elemento irracional sendo "naturalmente oposto ao princípio racional" 85 e apto a "lutar e resistir àquele princípio

\footnotetext{
80 À título de comparação, ver a afirmação de Aristóteles na Política de que "o intelecto regra os apetites com uma regra constitucional e real" nas The Basic Works of Aristotle, ed. Richard McKeon, New York: Random House, 1941, 1.5.1254b4.

81 ARISTOTELES, Física, em The Basic Works of Aristotle, 2.4.195b30-9.20oblo.

82 Ibidem, 2.1.192b22.

83 Ibidem, 2.1.193al-193b2.

84 ARISTÓTELES, Ética nicomaquéia, em The Basic Works of Aristotle, 1.7.1097b25-1098a5.

85 Enquanto Aristóteles e Cícero diriam "naturalmente oposto," Aquino descreveria esta oposição frequente como um efeito da Queda, e, portanto, a oposição seria "natural" no sentido
} 
racional" ${ }^{86}$. Assim Aristóteles já possui a explicação complexa e dinâmica de inclinações naturais hierarquicamente ordenadas e potencialmente opostas, que é tomada por Cícero.

Uma doutrina da lei natural é, de fato, delineada pela breve menção de Aristóteles de "povo descomedido" neste contexto, bem como em outras discussão sobre restrito e irrestrito no livro $7^{87}$. Nesta discussão tardia, Aristóteles descreve "descomedido" com referência aos "fatos da natureza humana"88. Esses fatos indicam a presença simultânea dentro do indivíduo de uma "opinião universal" que prescreve ou proíbe de acordo com a razão, e um "apetite" que resiste a estes comandos ${ }^{89}$. Deste modo "um homem se comporta desmedidamente sob a influência (em um sentido) de uma regra e uma opinião, e de um não contrário em si mesmo para a regra correta"90. Por essa razão, Aristóteles também afirma que "o mais baixo dos animais não é descomedido" precisamente porque "não tem juízo universal" que pertence somente à razão91.

O reconhecimento de Aristóteles de uma discussão complexa do fenômeno do comedimento e descomedimento acrescenta uma dimensão importante a sua filosofia moral que é frequentemente negligenciada por acadêmicos que tentam dissociar o "direito natural" aristotélico das teorias da lei natural. É dentro dessa discussão que Aristóteles apresenta uma análise da ação humana em geral como o produto ou conclusão de premissas universais e de uma premissa particular. As premissas universais consistem em proposições que expressam alguma verdade prática, tais como "alimento é bom para todos" ou "tal alimento é seco."92 Essas premissas

\footnotetext{
da natureza decaída, mas não natural no sentido da natureza original.

86 ARISTÓTELES, Ética, 1.13. 1102b 13-30.

87 Ibidem, 1102 b21.

88 Ibidem, 7. 3.1147a 25. 86.

89 Ibidem, 1147a30-5.

90 Ibidem, 1147a35-1147b2.

91 Ibidem, 1147b4-6.

92 Ibidem, 1147a5-7.
} 
universais ligam-se a comandos ou proibições gerais formulados pela razão e direcionados para o ser humano como um agente preocupado com ações particulares. No exemplo de Aristóteles, pode haver uma "opinião universal presente em nós," não apenas indicando que devemos abster-nos de realizar alguma ação, mas na verdade nos "impedindo" de realizar a ação93. Visto que Aristóteles não indica que sua análise da ação humana neste lugar se aplica somente a pessoas moderadas ou imoderadas, pode-se assumir que a pessoa de "sabedoria prática" discutida no livro imediatamente precedente semelhantemente possui premissas universais para ação que tem esta característica de comandar/proibir. O homem prudente, então, se distingue do homem descomedido nisso: visto que seus apetites ou paixões foram adequadamente habituados, eles não fazem surgir premissas concorrentes que impedem a eficácia da "regra correta."

Nesta análise da ação e da alma humana sobre a qual é baseada, o pensamento de Aristóteles parece aproximar de um conceito de lei natural. Embora Aristóteles não chegasse a este conceito por si mesmo, Cícero mostra em seus escritos que a noção de lei é na verdade implícita em uma explicação aristotélica da natureza humana ${ }^{94}$. Deste modo, Cícero põe a fundação para a teoria da lei natural no solo da natureza de Aristóteles.

Munidos com uma compreensão aristotélico-ciceroniana da lei natural, somente agora é possível dar uma interpretação adequada da afirmação culminante da lei natural "tradicional" (por falta de um termo melhor, nos escritos de Aquino). Em sua Summa Theologica, Aquino, como Cícero,

\footnotetext{
93 Ibidem, 1147a32. Embora o termo de Aristóteles aqui (koluousa) possa ser traduzido fracamente como "verificar" ou "prevenir" é mais frequentemente, e não por uma licença injustificada, traduzido como "proibir."

94 A questão de se Cícero leu as obras de Aristóteles ou era meramente familiarizado com o pensamento de seus seguidores na escola peripatética, não é de crucial importância especificamente para este argumento (assumindo uma quantia suficiente de continuidade entre as duas fontes). Porém, parece que Cícero de fato leu as obras de Aristóteles, em De Finibus 3. 10, p. 227.
} 
tenta derivar a lei natural de um encontro racional da realidade objetiva com uma explicação aristotélica da natureza dos seres humanos.

O chamado Tratado da le $i^{95}$ de Aquino é, certamente, não um tratado próprio, mas sim um relativamente pequeno grupo de questões que ocorrem no meio de uma empreitada muito maior. O tema da Summa é a ciência da "doutrina sagrada," cujo "principal objetivo é ensinar o conhecimento de Deus"96. Aquino dá um amplo esboço deste trabalho cuidadosamente estruturado na questão 2 da primeira parte, indicando que ele tratará de "Deus", do "movimento da criatura racional em direção a Deus", e de "Cristo, quem como homem, é nosso caminho para Deus." Sob o segundo tópico de pesquisa, Aquino considera "o último fim da vida humana" e "as coisas pelas quais o homem pode avançar para o fim, ou se afastar dele"97. O último tema concerne sobre os "atos humanos," cujo tratamento é primeiramente dividido em considerações "universais" e "particulares"98. Sob o título de universal, Aquino planeja tratar dos "atos humanos em si mesmos" e "seus princípios"99. A discussão dos princípios dos atos humanos começa na questão 49 da primeira parte da segunda parte, onde este assunto é novamente dividido em princípios "intrínse$\cos ^{\prime}$ e "extrínsecos. ${ }^{100}$. Finalmente chegamos nas questões sobre a lei no tratamento dos princípios "extrínsecos" dos atos humanos, que são identificados como o "mal" e "deus"101. O mal inclina as ações humanas ao mal através das "tentações", enquanto Deus inclina as ações humanas para o bem através da "lei" e "graça"102. Ao examinar a estrutura geral e a orientação da Summa, bem como o contexto da discussão da lei natural

\footnotetext{
AQUINO, ST, I.I, 9.90-108.

96 Ibidem, I.I, proemium.

97 Ibidem, I.I, q.1, proemium.

98 Ibidem, q.6, proemium.

99 Ibidem.

100 Ibidem, a.49, proemium.

101 Ibidem, q.90, proemium.

102 Ibidem.
} 
na categoria dos princípios "extrínsecos" dos atos humanos, é fácil negar o caráter puramente natural da lei natural de Aquino. Tal negação é paralela à afirmação de que, ao fazer da filosofia a "serva"103 da doutrina ou da teologia sagrada, Aquino viola a esfera apropriada do primeiro no interesse de propor o último ${ }^{104}$. A noção de que o método de Aquino não é verdadeiramente filosófico e que sua lei natural parece mais uma lei divina ou eterna, tem desfrutado ampla circulação ${ }^{105}$.

Não é surpresa, então, que o jusnaturalismo de Aquino é um foco particular daqueles que tentam refutar o jusnaturalismo em geral argumentando que ele exige fé em um deus legislador (e é ipso facto não meramente natural). O objetivo específico desta discussão, portanto, consistirá em traçar a derivação da lei natural de Aquino com um olhar atento para a usurpação potencial da lei divina ou eterna.

Primeiramente é importante notar que as questões sobre a lei são precedidas não somente por um tratamento de Deus mas também por uma investigação da natureza dos seres humanos. Esta investigação é de importância crucial para o entendimento da maneira que a lei natural de Aquino é "natural." Embora muitas interpretações contemporâneas da lei natural de Aquino corretamente enfatizem a importância do artigo sobre "se a lei natural contém vários preceitos ou somente um," ${ }^{106}$ um foco desproporcional neste artigo frequentemente leva a uma compreensão de "natureza" ou do "natural" que distorce a concepção de Aquino destes termos no caso dos seres humanos.

É neste artigo que Aquino avança sua bem conhecida teoria das "inclinações naturais" que são "naturalmente aprendidas pela razão como sendo

\footnotetext{
103 Ibidem, I, a.1, a.5, ad.2.

104 Ver a tradução de Fortin de ancilla como "escrava" de Aquino em History of Political Philosophy, p. 271. Enquanto "escrava" é uma tradução possível de ancilla, as conotações desta tradução vão ao encontro do espírito do uso de Aquino na ST.

105 Ver, por exemplo, FORTIN, St. Thomas Aquinas, e também Thomas Aquinas as a Political Thinker, Perspectives on Political Science 26, Spring, 1997, p. 92-7; ver também CROSSON, Religion and Natural Law, p. 8-13.

106 ST, I.II, q. 94, a. 2.
} 
boas." Se este artigo é lido solitariamente como a afirmação definitiva da lei natural de Aquino, parece natural que seja algo como pré-reflexivo, instintivo ou incorporado. Parece também que ao distinguir a "razão prática" da "razão especulativa"107 antes da discussão das inclinações dentro do artigo, Aquino significa dissociar o primeiro deste último e excluir o papel da razão especulativa ou reflexão contemplativa no funcionamento da lei natural. Se esta leitura for correta, duas conclusões relevantes para nossos propósitos são as seguintes: (1) A lei natural de Aquino não é derivada da compreensão filosófica da natureza humana que a precede na Summa; e (2) a lei natural de Aquino não continua com a versão aristotélico-ciceroniana que deriva os princípios da moralidade ou lei natural de uma compreensão especulativa ou reflexiva da natureza humana. Para combater estas conclusões e a leitura sobre a qual se baseiam, é necessário discutir como Aquino trata a natureza humana e determinar o papel que este tratamento tem na sua compreensão da lei natural.

Apesar do tema da primeira parte da Summa ser "Deus", Aquino inclui em sua consideração de Deus uma explicação do "itinerário das suas criaturas." 108 Ademais este caminho ocorre no triplo modo de "produção", "distinção" e "governo." ${ }^{109}$ Dentro do segundo modo, Aquino considera a distinção entre criaturas corpóreas e espirituais; depois de tratar de cada uma delas ele chega na "criatura composta, corpórea e espiritual, que é o homem." "110 Aquino divide sua consideração dos seres humanos em "natureza" e "origem." Enquanto a segunda discussão, sobre origem, explicitamente relaciona a criatura humana ao deus transcendente da teologia, a discussão da "natureza" do homem é completamente filosófica e desprovida de quaisquer premissas teológicas. Aquino baseia-se

\footnotetext{
107 Embora a extensão a qual Aquino significa distinguir as duas aplicações da razão, mesmo neste artigo está aberta à questão, visto que a distinção ocorre dentro de uma discussão da característica similar ou análoga dos dois tipos de raciocínios.

108 AQUINO, ST, I, q.2, proemium

109 Ibidem, q.44, proemium.

110 Ibidem, também q.75, proemium.
} 
fortemente nesta seção na descrição de Aristóteles da natureza humana derivada da Física, Da Alma, Analíticos posteriores e Ética.

A discussão de Aquino sobre a natureza humana se centra sobre uma consideração de seus "poderes", que posteriormente fornecem as bases para sua investigação sobre a maneira na qual a criatura racional se aproxima de Deus. Os poderes que Aquino fala não são no sentido de potestas (capacidade ou força) mas sim potentia (possibilidade) e virtus (virtude ou excelência) ${ }^{11}$. Nesse sentido os poderes da alma humana estão intrinsecamente ordenados para operação assim como a potencialidade está ordenada para a atualidade ${ }^{112}$.

Ao aprovar a classificação de Aristóteles, Aquino distingue cinco gêneros de poderes na alma humana: vegetativo, sensitivo, apetitivo, locomotivo e intelectual ${ }^{113}$. Em adição a sua mera distinção, estes tipos de poderes existem em uma ordem hierárquica que corresponde com a ordem entre os vários tipos de seres naturais. ${ }^{114}$ Os poderes vegetativo, sensitivo e intelectual determinam diferentes tipos de "almas" e "modos de viver" que são próprios às plantas, animais e humanos respectivamente ${ }^{115}$. A ordem entre esses tipos de alma e os modos de viver correspondentes surgem do grau para o qual cada "supera a operação da natureza corporal"116.

Ao determinar o nível de superioridade de certo tipo de alma para a natureza corporal, Aquino emprega a definição de Aristóteles de natureza como o princípio do movimento. O princípio próprio do movimento da matéria repousa em sua receptividade para um ímpeto "extrínseco" pelo qual ela é movida. O princípio próprio do movimento que une aos seres animados (isto é, seres com almas imateriais), por outro lado, repousa

\footnotetext{
1 Ver ST, I, q.75 e q.77, proemium.

112 Ibidem, 9.77, a.3, 110.

113 Ibidem, q. 78, a.I.

114 Ibidem; ver também I. q.77, a.4. Aqui nós achamos um ponto distinto de similaridade com as explicações de Aristóteles e Cícero.

115 Ibidem, q.78, a.l; ver também I, q. 18, a. 3.

116 Ibidem, q.78, a.l.
} 
em um princípio "intrínseco" pelo qual ele move a si mesmo"17a Portanto, cada tipo de alma excede a materialidade até o ponto em que ela permite o automovimento. Além disso, uma vez que a operação de automovimento admite grau de acordo com a forma como é realizada independentemente de determinados instrumentos materiais, uma menor dependência da materialidade corresponde a um maior grau de automovimento. A alma intelectual, que distingue os seres humanos dos outros animais e plantas, supera a materialidade no mais alto grau visto que ela não exige qualquer órgão material como seu instrumento ${ }^{118}$. Assim os seres humanos, na medida em que são humanos (isto é, possuem alma intelectual), se movem por si mesmos, pelo princípio intrínseco da intelectualidade.

Apesar do papel da intelectualidade ${ }^{119} \mathrm{em}$ distinguir e elevar a natureza humana com respeito a outras naturezas, é importante ter em mente o fato de que ela permanece tudo menos um tipo de poder entre cinco existindo em uma alma, que é a forma substancial de um corpo ${ }^{120}$. A consequência mais importante do último aspecto é que todo conhecimento intelectual adquirido pelos seres humanos ocorre per viam sensus ${ }^{121}$. Visto que é necessário que o conhecimento humano surja deste modo ${ }^{122}$, os seres humanos são intelectualmente inferiores aos anjos que não requerem fantasmas produzidos pelos sentidos ${ }^{123}$. O primeiro aspecto, ademais, sublinha o caráter composto do ser humano ao alocar sua intelectualidade dentro do contexto de sua natureza fundamentalmente "animal".

\footnotetext{
117 Ibidem.

118 Ibidem. Enquanto a alma intelectual não requer qualquer órgão ou instrumento, isso não nega a necessidade dos órgãos sensoriais materiais para a operação do intelecto, visto que todo conhecimento vem per viam sensus.

119 O intelecttus de Aquino é um equivalente fechado à ratio de Cícero e ao logos de Aristóteles em relação a concepção da natureza humana.

120 AQUINO, ST, I, q. 75, a. 5 e I, q. 76, a. 1.

121 Ibidem.a. 76, a. 5 .

122 Pelo menos enquanto no estado natural. Ver ibidem, q. 89, a. 1-2.

123 Ibidem, q. 85.1; também I, q. 79, a. 2.
} 
O primeiro aspecto sublinha ainda mais o caráter composto do ser humano colocando sua intelectualidade no contexto de sua natureza fundamentalmente "animal". Embora o intelecto eleve os humanos sobre os outros animais, ele não faz isso na medida de abandonar as características próprias que ligam as naturezas animais mais baixas ${ }^{124}$. $O$ elemento propriamente humano do homem coexiste com os elementos animal e vegetativo. À luz dessas considerações, Aquino afirma que "a alma humana está no limiar das criaturas espirituais e corporais, e, portanto, os poderes de ambos se reúnem na alma"125.

Aquino distingue dois "próprios" do intelecto que seguem sua apreensão: a "consideração da verdade" e a direção da operação ${ }^{126}$. Esta diferença na aplicação do poder intelectual resulta na distinção entre os intelectos "especulativo" e "prático"127. Visto que estes dois intelectos são realmente somente diferenças acidentais dentro do poder intelectual, há uma correspondência bem próxima entre os respectivos hábitos pelos quais eles estão dispostos a agir. Tanto o intelecto especulativo quanto o prático devem começar com primeiros princípios indemonstráveis que são cognoscíveis imediatamente por um encontro intelectual com o ser. Estes primeiros princípios são mantidos pelos hábitos do "entendimento"128 e "sindérese,"129 respectivamente. A partir desses pontos, ambas

\footnotetext{
124 Para uma comparação interessante, ver a crítica de Cícero da posição estoica no livro 4 do De Finibus.

125 AQUINO, ST, 1, a. 77, a. 2.

126 Ibidem, q. 79, a. 11-12.

127 Ibidem.

128 Ibidem, I.II, q. 57, a. 2.

129 Ibidem, I, q. 79, a. 12. O termo synderesis não é normalmente traduzido devido à falta de um equivalente inglês preciso. Porém é comumente compreendido como "consciência." Mas ele não pode ser traduzido como consciência visto que Aquino fala de conscientia no próximo artigo. O cardeal Joseph Ratzinger interessantemente traduz synderesis por anamnesis em seu artigo Consciência e verdade, apresentado no 10. ${ }^{\mathrm{a}}$ Oficina para bispos, em fevereiro de 1991. Ver: http://ewtn.com/library/curia/ratzcons.html.
} 
as manifestações do intelecto procedem por combinação para produzir conclusões, que são mantidas pelos hábitos da "ciência"130 e "prudência"131.

Apesar dessa analogia próxima entre as duas manifestações do intelecto, uma importante diferença surge em conexão com sua relação com a virtude. Virtudes, definidas de um modo aristotélico como hábitos que dispõem para o bem, são divididas por Aquino em dois tipos: aquelas que conferem "aptidão em fazer o bem" e aquelas que conferem "o bom uso" desta aptidão ${ }^{132}$. As virtudes do intelecto especulativo pertencem à primeira categoria, enquanto aquelas do intelecto prático pertencem à última. A disjunção entre hábito e ato, para a qual esta distinção das virtudes responde, tem sua fonte na indeterminação do apetite. As virtudes do intelecto prático levam diretamente a boas ações precisamente porque elas "pressupõem a retitude do apetite"133. A indeterminação do apetite assim necessita do cultivo das virtudes pelas quais sua "retitude" é assegurada.

No seu prólogo na segunda parte da Summa, Aquino explica que após tratar principalmente de Deus na primeira parte, "permanece para nós tratar de sua imagem, isto é, o homem, conforme como ele também é o princípio de suas ações, como tendo livre escolha e controle sobre suas ações." O poder da "livre escolha", que recai sob o poder apetitivo geral, surge do fato de que a "razão em assuntos contingentes, pode seguir direções opostas"134. Do "apetite racional" pelo qual os seres humanos são capazes de agir por um fim intelectualmente apreendido ${ }^{135}$ resulta que o homem "tem controle sobre suas ações", portanto, elas são "voluntárias." É a indeterminação da razão prática (ou intelecto) que tem

\footnotetext{
130 AQUINO, ST, I-II, q. 57, a. 2.

131 Ibidem, a. 4-5, 129.

132 Ibidem, a. 1.

133 Ibidem, a. 4.

134 Ibidem, I, q. 83, a. 1.

135 Ibidem, I.II, q. 6, a. 1.
} 
um papel decisivo em ambas as discussões do modo no qual os homens contêm os princípios de suas ações dentro de si mesmos.

Outra indeterminação na ação humana surge quando o intelecto, próprio dos seres humanos, confronta os outros poderes da alma humana que são compartilhados em comum com os animais. Uma vez que o poder sensível também é apreensivo (como o intelecto), dá origem ao próprio apetite cujo objeto pode contrariar o proposto pelo apetite intelectual ${ }^{136}$. Assim, ao defender a distinção entre virtude moral e intelectual da posição socrática, ${ }^{137}$ Tomás afirma que "a parte apetitiva obedece ao motivo, não cegamente, mas com certo poder de oposição"138. É por esta razão que a "retidão do apetite" inclui o apetite intelectual e o apetite sensual; o primeiro é aperfeiçoado pela justiça e pela prudência' ${ }^{139}$, enquanto o último é aperfeiçoado pela temperança e fortaleza ${ }^{140}$.

Ao fazer a transição de sua discussão das virtudes e vícios em sua consideração da lei, Aquino parece fazer a transição de princípios internos para externos da ação humana. Mas isso é parcialmente verdade. A distinção entre princípios intrínsecos e extrínseco no reino da ação humana não é tão clara quanto parece, como Aquino mesmo indica no início de sua discussão do tema. Ao tratar a questão de "se há algo voluntário nos atos humanos," Aquino afirma que não é contrário à natureza do ato voluntário que esse princípio intrínseco seja causado ou movido por um princípio extrínseco, porque não é essencial ao ato voluntário que seu princípio intrínseco seja um primeiro princípio ${ }^{147}$.

Em outras palavras, há um sentido onde homens e ações são completamente dependentes de um princípio extrínseco na medida em que

\footnotetext{
136 Ibidem, I, q.80, a.1.

137 Pelo menos como interpretado por Aristóteles na Ética 6.13.1144b19.

${ }_{138}$ AQUINO, ST, I.II, q. 58, a. 2. Note que esta é essencialmente uma paráfrase da descrição de Aristóteles dessa situação na Ética.

139 Ver lbidem, a. 61. a. 1.

140 Ibidem a. 2

${ }^{141}$ Ibidem, q. 6, a.1, ad.1.
} 
eles são dependentes de uma causa primeira de todo ser, isto é, Deus. No início de sua discussão sobre a lei ${ }^{142}$, ademais, Aquino não lista "lei" como um dos princípios extrínsecos com o qual ele está preocupado. Os únicos princípios extrínsecos indicados são "o mal" e "deus". Cada um desses princípios extrínsecos opera por certas causas instrumentais; o mal através das "tentações" e Deus através da "lei" e "graça." A graça, porém, é antes, descrita como um "hábito", isto é, um princípio interno da ação humana, que reside na essência da alma ${ }^{143}$. Simplesmente não se segue que se Deus é um princípio extrínseco das ações então ele só pode agir por causas puramente instrumentais e extrínsecas. Não há nada na Summa que indique a priori que a noção de lei é extrínseca, intrínseca ou alguma combinação de ambas.

Entretanto, isso não significa que a alocação da lei natural dentro do princípio extrínseco é acidental ou coincidência. Aquino inicia sua consideração da lei natural com provas para a existência de um deus transcendente que governa toda sua criação. Isso torna possível uma derivação da lei natural dentro do contexto de sua relação com a lei eterna de deus. O que está presente na derivação da lei natural de Cícero de um modo relativamente superficial e conjectural é assim presente de um modo fundamental e certo para Aquino. Visto que Aquino está certo da "coerência do todo"144 tanto pela luz da fé quanto do testemunho da razão, ele vê a lei natural do mesmo modo que ele vê a criação com um todo: "à luz da eternidade"145.

Portanto, é consistente com a perspectiva geral de Aquino definir a lei natural como a "participação da lei eterna na criatura racional." ${ }^{146}$ Essa inclusão da "lei eterna" na real definição da lei natural leva muitos comentadores a recusar a verdadeira "naturalidade" da última. Sob

\footnotetext{
142 Ibidem, q. 90, proemium.

143 Ibidem, q. 50, a. 2.

144 SCHALL, James. The Uniqueness of the Political Philosophy of Thomas Aquinas, Perspectives on Political Science 26, Spring, 1997, p. 89.

145 FORTIN, Thomas Aquinas as a Political Thinker, p. 92.

146 AQUINO, ST, I.II, q. 91, a. 2.
} 
exame mais acurado, porém, a "participação da criatura racional" descrita por Aquino é de fato bem diferente da coerção divina com a qual é frequentemente equacionada.

Apesar de Aquino definir a lei em geral como algo "pertencente à razão"147, ele distingue dois tipos no qual essa relação de razão por ocorrer: primeiro, "como em alguém que governa" e segundo, "por participação, como em alguém que é governado"148. A lei eterna claramente pertence à razão no primeiro sentido já que ela é "a real ideia do governo das coisas em Deus"149. Como a lei eterna se aplica às criaturas sem intelecto ou razão, ela tem a característica da lei simplesmente por virtude da razão divina como um princípio externo. Se a legalidade da lei natural fosse semelhantemente derivada somente da razão divina associada com a lei eterna, o tratamento de Aquino dela como um tipo de lei distinta da lei eterna seria amplamente inexplicável. Da definição da lei natural, porém, está claro que ela alcança reconhecimento como uma lei por pertencer à razão no segundo sentido, isto é, "por participação"150. Para a criatura racional, esta parte da lei eterna que se aplica a ele externamente é internalizada pelo poder do intelecto que apreende a ordem estabelecida dentro da natureza humana pela razão eterna. Essa ordem manifesta-se na "ordem das inclinações naturais" dentro dos seres humanos, cuja discussão está intimamente relacionada com os “instintos” pertencentes aos vários níveis do ser natural'51. Assim, a lei natural é aquela pela qual "discernimos o que é bom e o que é mau"152 em vez de simplesmente aquela pelo qual nosso verdadeiro bem e perfeição é prescrito externamente.

\footnotetext{
147 AQUINO ST. I.II, a. 90, a.1.

148 Ibidem, a. 3, ad.1.

149 Ibidem, q. 91, a.1.

150 Ver Ibidem, a. 2, ad. 3.

151 A discussão de Aquino ocorre em ST. I.II, q.91, a.2 e I.II, q.94, a.2. Uma discussão semelhante de Cícero ocorre no De officiis, iniciando em 1.11, p. 13 (ver p. 503 [na paginação do artigo original. N.T]).

152 AQUINO, ST, I.II, q. 9, a. 2 (ênfase minha).
} 
Esse argumento pode também ser ilustrado por uma analogia no campo da razão especulativa. Suponha que alguém desenhasse um triângulo reto numa folha de papel e postasse esta folha em um mural para todos verem (ou talvez na homepage do Google). Depois de verem este triângulo um número de vezes e terem formado uma imagem dele em suas mentes, todos saberiam suas características básicas, a saber, que a hipotenusa é maior do que qualquer um dos dois lados, que o ângulo direito é maior do que qualquer um dos outros dois lados e assim por diante. As mentes mais acuradas iriam muito mais longe, e deduziriam que o ângulo reto é igual à soma dos outros dois ângulos, o quadrado da hipotenusa é igual à soma dos quadrados nos outros dois lados etc. Todo este corpo de conhecimento, porém, é derivado e implícito do modo no qual o triângulo foi originalmente desenhado. De fato, quem desenhou o triângulo foi Euclides, que o fez com um conhecimento não só de seus atributos mais complexos, mas também daqueles de muitos outros tipos de figuras que podem ser desenhadas. Como o conhecimento que agora existe nos observadores do triângulo preexistiu em Euclides e foi, em parte, extrinsecamente causado por sua ação de desenhá-lo, devemos negar a esses observadores a posse interna desse conhecimento? Euclides infundiu os teoremas sobre o triângulo nos observadores só por desenhá-lo desse jeito? Não é mais razoável admitir que, enquanto a ação de Euclides foi um princípio extrínseco do conhecimento dos observadores, esse conhecimento é agora a posse compartilhada tanto de Euclides quanto daqueles que racionalmente encontraram este triângulo?

Além de estabelecer o caráter "lícito" da lei natural, essa discussão também ilumina o modo como a lei natural de Aquino é verdadeiramente "natural", isto é, não depende da ordem do conhecimento ${ }^{153}$ sobre a lei eterna ou Divina Razão de onde a lei eterna emana. Uma vez que a lei eterna se reflete na ordem objetiva dentro e entre os seres criados,

153 Neste ponto a distinção que Finnis delineia entre as ordens "epistemológica" e "ontológica", que é apresentada tanto ao longo da Summa como da Física de Aristóteles, se torna relevante. 
incluindo o ser humano, tudo o que é necessário para a compreensão dos primeiros princípios da lei natural é o procedimento intelectual da indução da realidade objetiva ${ }^{154}$. Uma vez que, além disso, isso a derivação decorre da indução em vez da demonstração, esses princípios são, de fato, nota per se e indemonstrabilia, embora não da maneira como esses termos são entendidos por muitos novos jusnaturalistas ${ }^{155}$.

Para Aquino, "todo conhecimento da verdade é um tipo de reflexão e participação da lei eterna"156, e assim recai na definição da lei natural na medida em que esta verdade dirige o homem para o bem de sua natureza. As verdades mais básicas que são relevantes para a ação humana, tal como a superioridade do intelecto para os poderes sensitivos (correspondente à superioridade dos homens sobre outros animais), são apreendidas pela indução do intelecto e sustentadas habitualmente pela sindérese. Assim o preceito fundamental da lei natural consiste para Aquino no comando geral de que "o bem deve ser perseguido e o mal evitado." 157 Aquino explica o sentido de seu primeiro preceito afirmando que "o que a razão prática apreende como o bem do homem pertence aos preceitos da lei natural." ${ }^{158}$ O "bem" então, consiste primeiro e acima de tudo em o estado geral de viver de acordo com a natureza humana de alguém (isto é, agir sob as indicações da apreensão intelectual). Desta forma, a lei natural de Aquino também possui o duplo e flexível caráter da derivação de Cícero; a partir da primeira e mais básica injunção para seguir a razão, as aplicações mais específicas da razão também adquirem o caráter da lei, comandando os apetites de pessoas envolvidas em ações concretas.

\footnotetext{
154 Ver AQUINO, ST, I.II, q. 93, a. 2.

155 A compreensão dos princípios indemonstráveis pelos novos jusnaturalistas não inclui qualquer explicação positiva, tal como a fornecida pelo processo de indução, mas somente a afirmação negativa de indemonstrabilidade.

156 AQUINO, ST, I.II, a. 93, a. 2.

157 Ibidem, q. 94, a. 2.

158 Ibidem.
} 


\section{III}

Ao alocar a doutrina da lei natural de Aquino dentro de seu contexto mais amplo na Summa, isto é, dentro de uma filosofia da natureza humana, se torna possível discernir tanto as raízes aristotélicas desta doutrina e a importância de Cícero como um intermediário crucial entre a filosofia moral aristotélica e a lei natural aquiniana. Se Cícero não tivesse mostrado que uma compreensão aristotélica da natureza humana era compatível com, ou mesmo implicada, uma teoria da lei natural, Aquino provavelmente não teria tido os recursos necessários para distinguir a lei natural como um tipo de lei diferente tanto da lei eterna e divina. A lei natural aquiniana é, então, uma afirmação desenvolvida de uma teoria da lei natural "tradicional" que conta Cícero e Aristóteles por ele, como seus membros fundadores.

É importante notar e abordar brevemente duas objeções imediatas a esta interpretação da teoria da lei natural aquiniana antes de concluir. A primeira afirma que Santo Agostinho é o candidato mais óbvio na influência sobre a lei natural de Aquino do que Cícero. ${ }^{59}$ É Santo Agostinho que "suporta" a questão sobre a lei natural, aparecendo no sed contra do primeiro e último artigo da questão $94 .{ }^{160}$ Cícero, por outro lado, não é citado uma única vez.

Para responder a essa objeção, deve primeiro ser notado que a função do sed contra no método de Aquino é se opor à força das objeções com uma autoridade suficiente para pôr em dúvida sobre sua cogência. Embora as afirmações de autoridade geralmente suportem a própria resposta de Aquino, essa resposta é frequentemente posta sobre uma base completamente diferente, por exemplo, Aquino muitas vezes cita as Escrituras nas sed contra antes de fornecer uma resposta puramente filosófica para a questão. As mais fortes influências sobre o próprio pensamento de

\footnotetext{
159 Esta objeção é delineada de FORTIN, The Problem of Natural Law, p. 191-199, e KEYS, Mary. Aquinas, Aristotle, and the Promise of the Common Good, Cambridge: Cambridge University Press, 2006, p. 102-110. Embora Keys argumente aqui pela "novidade da fundação moral de Aquino", ao invés da força da influência de Agostinho, a forma do argumento usada favoreceria Agostinho ao invés de Cícero, como uma influência sobre a doutrina da lei natural de Aquino. 160 Notado em KEYS, Promise of the Common Good, Cambridge University Press, 2006, p.108.
} 
Aquino podem ser esperadas para aparecer em seu respondeo ao invés dos sed contra. Ademais, visto que é dentro de sua própria resposta que Aquino mostra o que ele percebe como verdade da questão, referência específica às suas fontes se tornam menos necessárias. Apesar de Aquino frequentemente fornecer tais referências em suas respostas, na medida em que ele mostra a verdade da questão, a ausência de uma referência específica não argumenta pela ausência de qualquer precedente para suas afirmações ${ }^{161}$. A razão para isso é que a verdade, em contraste com declarações autoritativas consideradas em si, é um bem comum e não particular. Portanto opiniões e argumentos perdem sua ligação exclusiva para seres humanos particulares na medida em que eles se aproximavam da verdade atual. Assim, enquanto referências específicas fornecem clara evidência de algum grau de influência, uma similaridade de ideias e argumentos sem referência específica podem de fato indicar até mesmo uma afinidade mais próxima ao pensamento precedente para Aquino.

Ademais Cícero é citado por Aquino tanto dentro do Tratado da lei $i^{162}$ e, com alguma frequência, na Prima Secundae ${ }^{163}$. Está claro nestas citações que Aquino tinha familiaridade com o De inventione de Cícero, com as Tusculanae Disputationes e com o De officiis ${ }^{164}$, e que ele considerava Cícero com uma autoridade respeitável em moral e política. A questão 94, então, pode somente ser persuasivamente isolada da influência de Cícero com um argumento de referência específica (ou uma falta dele) na medida em que esta questão em si mesma pode ser entendida isoladamente do restante das questões sobre a lei na Summa como um todo.

Uma segunda objeção pressiona o ponto, brevemente anotado acima, de que essa explicação da teoria da lei natural continua a ser vulnerável

\footnotetext{
${ }^{161}$ Ver o argumento ibidem, 107-110.

162 AQUINO, ST, I.II, q. 91, a 3; I.II, q. 95, a. 3, obj. 3; I.II, q. 99, a. 5, ad.1.

163 Para um índice destas citações, ver St. Thomas Aquinas, Basic Writings of Saint Thomas Aquinas, ed. Anton C. Pegis, New York: Random House, 1945, p. 1164.

${ }^{164}$ Aquino era familiarizado com trechos de outras obras de Cícero através dos escritos de Agostinho.
} 
à "falácia naturalista" ou à derivação dos valores dos fatos ${ }^{165}$. Por esse motivo, a explicação dada pode ser de interesse para o historiador das ideias, mas não pode servir para reabrir a questão filosófica da existência de uma lei natural em sentido estrito. Embora uma resposta suficiente a essa objeção se estenda necessariamente muito além do que pode ser tentado aqui, pode ser possível esboçar os contornos e a direção de tal resposta, observando brevemente alguns pontos de relevância.

A impossibilidade lógica de inferi-la ou derivar os valores dos fatos é geralmente traçada até a famosa afirmação de Hume do problema do "ser e dever ser." ${ }^{166}$ Este problema, tanto em seu contexto original dentro do pensamento de Hume e em suas várias outras formulações recentes, segue de uma limitação específica dos poderes da razão. Embora a razão seja capaz de deduções complexas e filosofia abstrusa, é incapaz de fazer indução aristotélica ou a mais primitiva função de abstrair ideias que são uma vez gerais e verdadeiras de experiências sensoriais particulares. Assim a razão fica em uma considerável distância do campo da realidade concreta dentro do qual as ações humanas particulares acontecem, e por esta distância é considerada incompetente para realizar sua função tradicional de guiar para a virtude e impedir o vício. A disjunção ser-dever, então, está intimamente conectada com o profundo ceticismo de Hume.

Embora os novos jusnaturalista tendam a negar tal conexão, simultaneamente afirmando a validade da distinção ser-dever de Hume e a habilidade da razão prática em compreender a verdade moral objetiva, esta negação repousa sobre uma dúbia e rígida distinção entre as atividades da razão prática e especulativa. O rigor desta distinção carece de uma base persuasiva nos escritos de Aquino e torna o significado de "inteligência" ou razão problematicamente indeterminado. Parece difícil, então, aceitar a impossibilidade da inferência fato-valor sem colocar uma epistemologia radicalmente cética em sua base.

165 Ver FINNIS, Natural Law, p. 33 e GEORGE, Natural Law and Human Nature, p. 32.

166 HUME, A Treatise of Human Nature, Baltimore, Md: Penguin Books, 1969, livro 3, parte 1, §1. 
Assim, enquanto a Summa Theologica de Aquino permanece o locus clássico para a teoria da lei natural, assim a teoria adquire mais força e persuasão quando é colocada no topo de uma tradição precedente de pensamento do que quando é relegada para o sopé de uma tradição emergente. Parece que a transição moderna da lei natural tradicional para a nova lei natural pode, de fato, ter sido prematura; e se este for o caso, o que é exigido para a teoria atual da lei natural não é o abandono da versão mais tradicional, mas sim seu desenvolvimento e aplicação aos problemas urgentes da sociedade contemporânea.

\section{Referências}

AQUINAS, Thomas. Basic writings of Saint Thomas Aquinas. New York: Random House, 1945.

AQUINAS, Thomas. Summa theologica. New York: Benziger Bros, 1948.

ARISTOTLE. The basic works of Aristotle. New York: Random House, 1941.

ARKES, Hadley. That nature herself has placed in our ears a power of judging: some reflections on the naturalism of Cícero. In: GEORGE, Robert P. (ed.). Natural law theory: contemporary essays. Oxford: Oxford University Press, 1992.

CICERO, Marcus Tullius. De finibus bonorum et malorum. Tradução H. Rackham. Cambridge: Harvard University Press, 2006.

CICERO, Marcus Tullius. De legibus. Tradução C. W. Keyes. Cambridge: Harvard University Press, 1970.

CICERO, Marcus Tullius. De officiis. Tradução Walter Miller. Cambridge: Harvard University Press, 2001.

CICERO, Marcus Tullius. De re publica. Tradução C. W. Keyes. Cambridge: Harvard University Press, 1970.

CROSSON, Frederick. Religion and natural law. The American Journal of Jurisprudence, [s. l.], v. 33, n. 1, p. 1-17, 1988. https://doi.org/10.1093/ajj/33.1.1 FINNIS, John. Natural law and natural rights. Oxford: Oxford University Press, 1980. 
FINNIS, John; GRISEZ, Germain. The basic principles of natural law: a reply to Ralph Mclnerny. The American Journal of Jurisprudence, [s. l.], v. 26, n. 1, p. 21-31, 1981. https://doi.org/10.1093/ajj/26.1.21

FORTIN, Ernest L. Augustine, Thomas Aquinas, and the problem of natural law. Mediaevalia, Porto, v. 4, p. 179-208, 1978.

FORTIN, Ernest L. The new rights theory and the natural law. Review of Politics, Notre Dame, v. 44, n. 4, p. 590-612, Oct. 1982. https://doi.org/10.1017/ So034670500041504

FORTIN, Ernest. Thomas Aquinas as a political thinker. Perspectives on Political Science, Washington, v. 26, n. 2, p. 92-96, 1997. https://doi. org/10.1080/10457099709600667

GEORGE, Robert. Natural law and human nature. In: GEORGE, Robert (org.). Natural law theory: contemporary essays. Oxford: Oxford University Press, 1992. p. 31-41.

HOLTON, James. Marcus Tullius Cícero. In: STRAUSS, Leo; CROPSEY, Joseph (ed.). History of political philosophy. 3. ed. Chicago: University of Chicago Press, 1987.

HORSLEY, Richard A. The law of nature in Philo and Cícero. The Harvard Theological Review, [s. l.], v. 71, n. 1/2, p. 35-59, Jan./Apr. 1978. https://doi. org/10.1017/So017816000025566

HUME, David. A treatise of human nature. Baltimore: Penguin Books, 1969.

KEYS, Mary. Aquinas, Aristotle and the promise of the common good. Cambridge: Cambridge University Press, 2006. https://doi.org/10.1017/CBO9780511498213

MCARTHUR, Ronald. The natural law: a perennial problem. The American Journal of Jurisprudence, [s. l.], v. 26, n. 1, p. 1-20, 1981. https://doi.org/10.1093/ aji/26.1.1

NICGORSKI, Walter. Cícero and the rebirth of political philosophy. The Political Science Reviewer, [s. l.], v. 8, p. 63-102, 1978.

NICGORSKI, Walter. Cicero's paradoxes and his idea of utility. Political Theory, Beverly Hills, v. 12 , n. 4, p. 557-578, Nov. 1984. https://doi. org/10.1177/0090591784012004006

SCHALL, James V. The uniqueness of the political philosophy of Thomas Aquinas. Perspectives on Political Science, Washington, v. 26, n. 2, p. 85-91, 1997. https://doi.org/10.1080/10457099709600666 
SIGMUND, Paul. Natural law in political thought. New York: University Press of America, 1971.

STRAUSS, Leo. Natural right and history. Chicago: University of Chicago Press, 1953.

WEINREB, Lloyd. Natural Law and Justice. Cambridge: Harvard University Press, 1987.

WOLFE, Christopher. Natural law liberalism. Cambridge: Cambridge University Press, 2006. https://doi.org/10.1017/CBO9780511509704

ZUCKERT, Michael. The fullness of being: Thomas Aquinas and the modern critique of natural law. The Review of Politics, [s. l.], v. 69, n. 1, p. 28-47, 2007. https://doi.org/10.1017/So034670507000307

\section{Endereço Postal:}

Universidade Federal do Paraná - Setor de Ciências Humanas - Filosofia Rua Dr. Faivre, $405-6^{\circ}$ andar - Ed. D. Pedro II, CEP: 80060-140 - Curitiba - Paraná - Brasil , Departamento de Filosofia 